\title{
Microbiota in swine wastewater treatment plant and area of Tifton 85 grass production
}

\section{Microbiota da água residuária de suinocultura na estação de tratamento e área de produção de capim-tifton 85}

\author{
Jaqueline Rocha Wobeto Sarto ${ }^{1 *}$; Marcela Abbado Neres ${ }^{2}$; Samantha Mariana \\ Monteiro Sunahara ${ }^{3}$; Caroline Daiane Nath ${ }^{4}$; José Renato Stangarlin ${ }^{5}$; Marcos \\ Vinicius Mansano Sarto ${ }^{6}$
}

\begin{abstract}
The objective of this study was to evaluate the effects of biodigester treatment on the microbiological characteristics of swine wastewater (SW) at the production and storage sites, and to characterize and compare the microbiological composition of the soil, organic matter, and plants in the area of hay and haylage production. The area has been planted with Tifton 85 grass for eight years; and is exclusively intended for hay and haylage production, SW was used as the only fertilizer source. The experimental design was completely randomized with subdivided plotsin timeand five replications; the plots were the main areas of the SW in natura (affluent), the biodigester outlet (effluent), the storage pond, and the area of Tifton 85 production, which included the soil, plant residue on the soil surface (organic matter), and the aerial parts of the grasses with subplots in the rainy and dry seasons. The microbial count in the SW was reduced during the treatment process, with higher counts in the affluent, and lower counts in the effluent and storage pond. The SW treatment was efficient in reducing the microbial population. The populations of Bacillus and Clostridium were influenced by the season of the year, with larger populations during the rainy season (summer) than during the dry season (winter). The mold genera identified in the SW area were Penicillium, Rhizopus, Fusarium, Helminthosporium, and Phoma. The genera Penicillium, Rhizopus, Fusarium, Cladosporium, Helminthosporium, Bipolaris, Phoma, Aspergillus, and Trichoderma were found in the area of Tifton 85 production.
\end{abstract}

Key words: Forage. Manure. Microorganisms. Soil.

\section{Resumo}

O objetivo deste estudo foi avaliar a eficiência do tratamento do biodigestor nas características microbiológicas da água residuária de suinocultura (ARS), no local de produção até o local de armazenamento, bem como caracterizar e comparar a composição microbiológica do solo, matéria

1 Discente, Curso de Doutorado do Programa de Pós-Graduação em Zootecnia, Faculdade de Medicina Veterinária e Zootecnia, Universidade Estadual Paulista, FMVZ/UNESP, Botucatu, SP, Brasil. E-mail: jaquelinerwsarto@gmail.com

2 Prof ${ }^{a}$, Departamento de Zootecnia, Universidade Estadual do Oeste do Paraná, UNIOESTE, Marechal Cândido Rondon, PR, Brasil.E-mail: marcela.neres@unioeste.br

3 M.e em Zootecnia, UNIOESTE, Marechal Cândido Rondon, PR, Brasil. E-mail: samanthasunahara@yahoo.com.br

4 Discente, Curso de Doutorado do Programa de Pós-Graduação em Zootecnia, UNIOESTE, Marechal Cândido Rondon, PR, Brasil. E-mail: karolynedayane@hotmail.com

5 Prof., Departamento de Agronomia, UNIOESTE, Marechal Cândido Rondon, PR, Brasil. E-mail: jose.stangarlin@unioeste.br

6 Discente, Curso de Doutorado do Programa de Pós-Graduação em Agronomia, Faculdade de Ciências Agronômicas, FCA/ UNESP, Botucatu, SP, Brasil. E-mail: marcos.sarto28@gmail.com

* Author for correspondence 
orgânica e planta, em uma área de produção de feno e pré-secado. A área de capim-tifton 85 foi implantada há oito anos e é destinada exclusivamente à produção de feno e pré-secado, utilizando como única fonte de adubação a aplicação da ARS. O delineamento experimental foi inteiramente casualizado com parcelas sub divididas, com cinco repetições, sendo as parcelas principais: ARS in natura (afluente), a ARS após a saída do biodigestor (efluente) e a ARS na lagoa de armazenamento; além da área de produção do capim-tifton 85: solo, resíduo das plantas na superfície do solo (matéria orgânica) e parte aérea da planta. As sub parcelas foram: a estação chuvosa e a estação seca. Os resultados mostram que a carga microbiana presente na ARS foi reduzida durante o processo de tratamento, com maiores contagens no afluente, e menores no efluente e lagoa de armazenamento. O tratamento da ARS foi eficiente na redução da população microbiana. A população de Bacillus e Clostridium é influenciada pela estação do ano, com maiores populações na estação chuvosa (verão) em relação à estação seca (inverno). Os gêneros de bolores identificados na área de produção da ARS foram Penicillium, Rhizopus, Fusarium, Helminthosporium, Phoma. Na área de produção do capim-tifton 85 foram encontrados os gêneros Penicillium, Rhizopus, Fusarium, Cladosporium, Helminthosporium, Bipolaris, Phoma, Aspergillus, Trichoderme.

Palavras-chave: Forragem conservada. Micro-organismos. Forragem. Solo. Planta.

\section{Introduction}

The production of swine wastewater (SW) has increased because of agricultural growth, and it can be used for replenishing soil fertility. However, if improperly disposed, it may compromise the quality of groundwater, result in the emission of polluting gases, and cause impacts on the health problems of soil organisms (PESSUTO et al., 2016). Therefore, effective and economical methods have been used to treat swine manure, and minimize waste for the recovery of bioenergy (ZHOU et al., 2016).

Anaerobic digestion is an important economical alternative for the treatment of manure (KORZENIEWSKA et al., 2014; HAMAWAND, 2015; YAN et al., 2015). It is widely regarded as an optimal approach to organic waste treatment, since this process results in the production of sustainable energy and wastethat can be used as an agricultural fertilizer (POSCHL et al., 2010). Consequently, manure can be transformed into a valuable raw material (MATA-ALVAREZ et al., 2014).

According to Menezes et al. (2003), it is considered that the amount of wastewater produced per pig per day is 12 to 15 liters, depending on the productive phase. As a result, the use of SW has enabled the cultivation of fodder crops in some regions because ofitsabilityto totally or partially replace chemical fertilizers, and simultaneously, it can be used to resolve environmental problems.

The use of SW as a fertilizer for forage crops is a common andwell-established practice. Despite the abundance of literature on irrigation with SW (MULLER et al., 2013; MENEZES et al., 2003), most research studies focus on its effects on plant growth and development, although irrigation with SW may also pose risks to the forage quality of the crops. Therefore, it is of interest to characterize the microbiological composition of SW, since it affects the sanitary quality of forage, mainly because of the occurrence of pathogenic bacteria and molds that produce mycotoxins.

It is important to identify and characterize the genotypes of the predominant molds and other microorganisms that thrive during the stages of forage production, since the presence of large populations of pathogenic molds that produce mycotoxins, particularly, in hay compromises the health of the animals by the induction of carcinogenic and hepatotoxic effects, and mutagenesis (FREIRE et al., 2007). 
Few studies have focused on the microbiological characterization of SW that is utilized to irrigate the area of production of the hybrid bermudagrass, Tifton 85. Thus, our hypothesis was that the treatment process could reduce the microbial populations in SW, which differ according to the season of the year. Additionally, it is not known if the population of microorganisms that is present in SW remains in the soil, on the aerial parts of the Tifton 85 grasses and in organic matter after the irrigation of Tifton 85 with SW. The objective of this study was to evaluate the effects of biodigester treatment on the microbiological characteristics of SW as it is transported from the production to the application site, as well as to characterize and compare the microbiological composition of the soil, organic matter, and plants in the area of hay and haylage production.

\section{Material and Methods}

The experiment was carried out in Marechal CândidoRondon, Paraná, Brazil, whose geographical coordinates are $24^{\circ} 33^{\prime} 40^{\prime \prime} \mathrm{S}, 54^{\circ} 04^{\prime} 12^{\prime \prime} \mathrm{W}$, with an elevation of $420 \mathrm{~m}$. According to Köppen the type of climate in this region was $\mathrm{Cfa}$, which is described as a subtropical climate with well distributed rains during the year and hot summers. The climatic conditions at the collection stations are described in Figure 1.

Figure 1. Precipitation, maximum and minimum temperatures and relative humidity during rainy season (November, a) and dry season (June, b) in Marechal Cândido Rondon, Paraná, Brazil.

a)

Precipitation $(\mathrm{mm})$

$-\mathrm{T} \operatorname{Max}\left({ }^{\circ} \mathrm{C}\right)$

-..-.-.. T Mín $\left({ }^{\circ} \mathrm{C}\right)$

$\longrightarrow \mathrm{RH}(\%)$

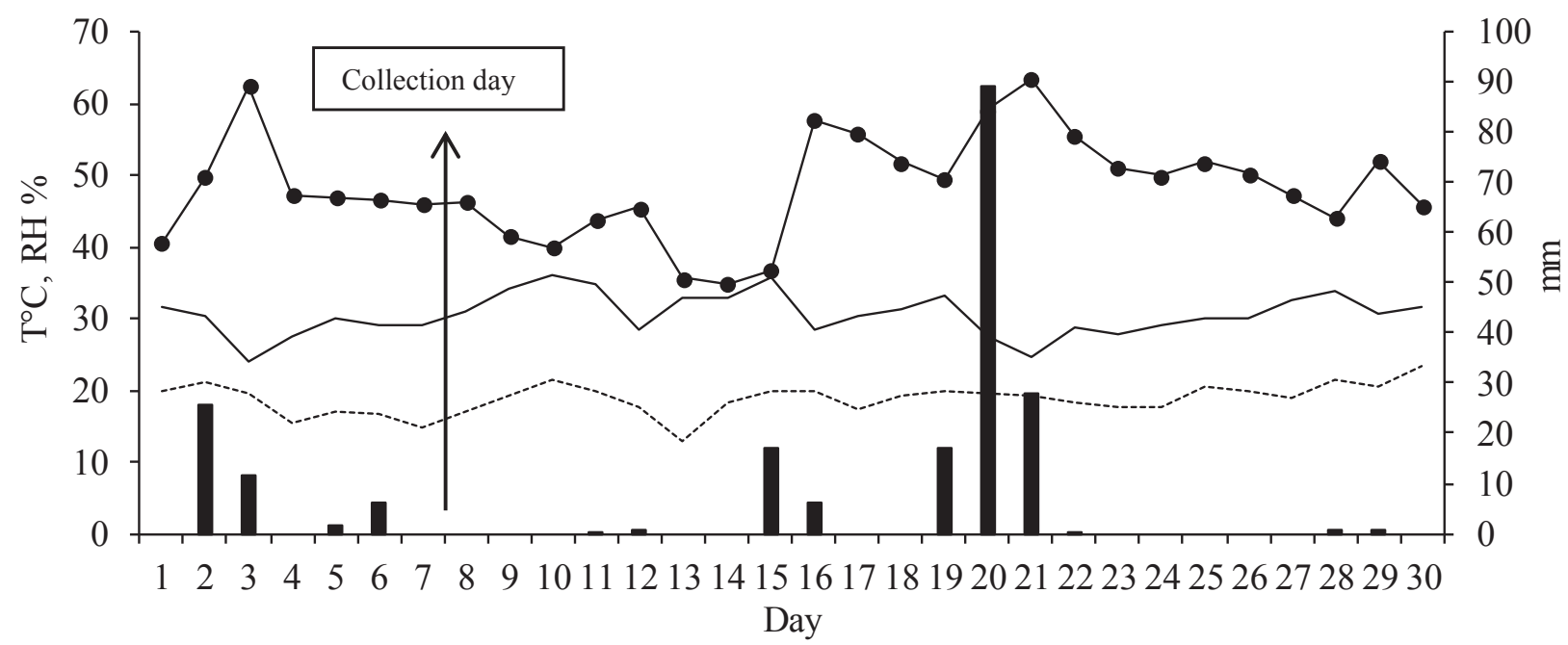




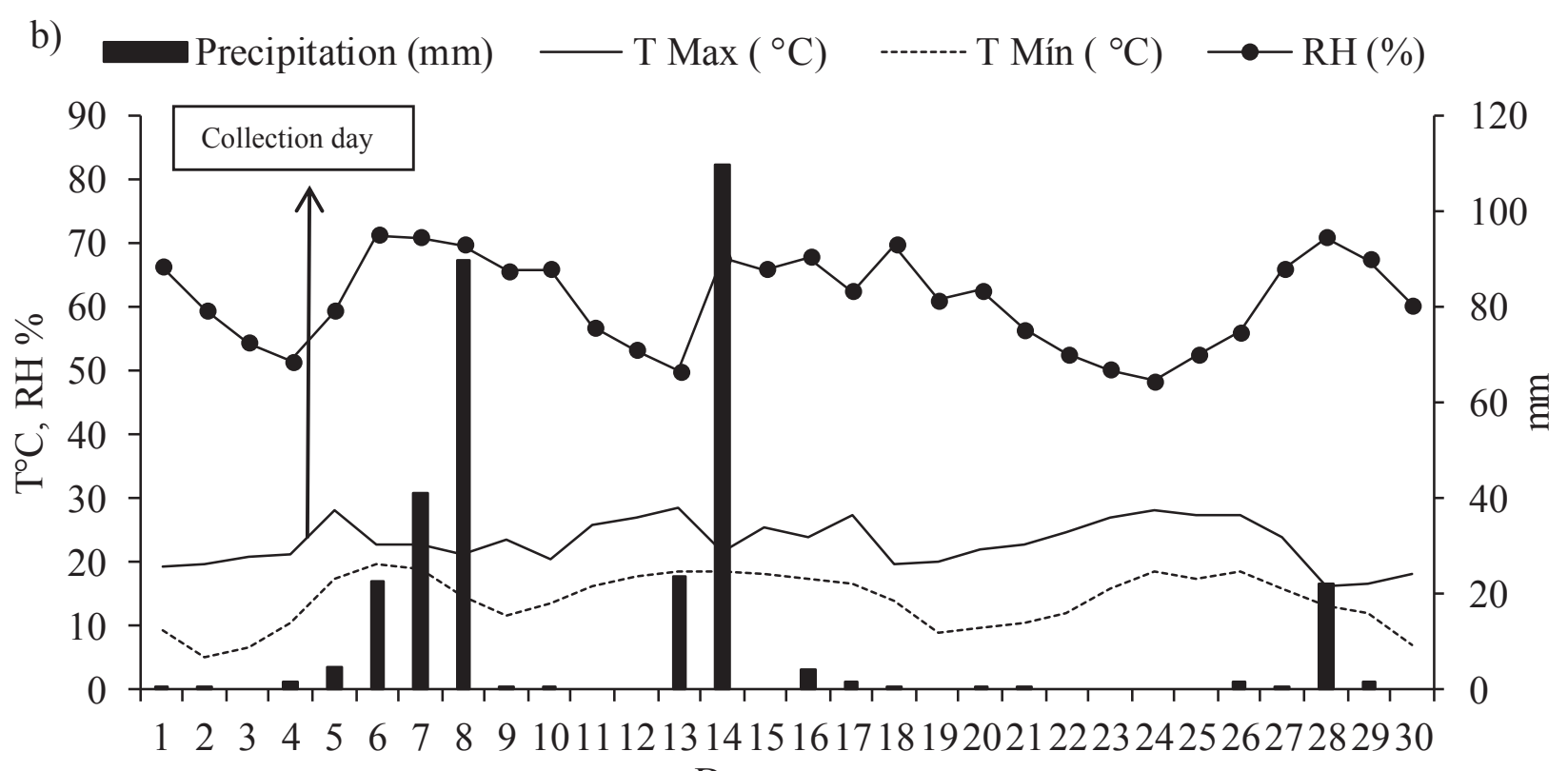

Day

The soil was classified as eutrophic Red Latosol (EMBRAPA, 2013) and it exhibited the following chemical attributes: $\mathrm{pH}\left(\mathrm{CaCl}_{2}\right)$ of 5.73; $\mathrm{P}$ (Mehlich-1) of $30.64 \mathrm{mg} \mathrm{dm}^{-3}$; K (Mehlich-1) of $0.17 \mathrm{cmol} \mathrm{dm}^{-3} ; \mathrm{Ca} 2+\left(\mathrm{KCl} 1 \mathrm{~mol} \mathrm{~L}^{-1}\right)$ of $7.41 \mathrm{cmol}_{\mathrm{c}}$ $\mathrm{dm}^{-3} ; \mathrm{Mg}^{2+}\left(\mathrm{KCl} 1 \mathrm{~mol} \mathrm{~L}^{-1}\right)$ of $2.47 \mathrm{cmol}_{\mathrm{c}} \mathrm{dm}^{-3} ; \mathrm{Al}^{3+}$ $\left(\mathrm{KCl} 1 \mathrm{~mol} \mathrm{~L}^{-1}\right)$ of $0.00 \mathrm{cmol}_{\mathrm{c}} \mathrm{dm}^{-3} ; \mathrm{H}+\mathrm{Al}$ (calcium acetate $\left.0.5 \mathrm{~mol} \mathrm{~L}^{-1}\right)$ of $3.14 \mathrm{cmol} \mathrm{dm}_{\mathrm{c}}^{-3}$; SB of 10.05 $\mathrm{cmol}_{\mathrm{c}} \mathrm{dm}^{-3}$, CTC of $13.19 \mathrm{cmol}_{\mathrm{c}} \mathrm{dm}^{-3}$; V of $73.2 \%$, organic matter (Boyocus Method) of $15.04 \mathrm{~g} \mathrm{dm}^{-3}$; $\mathrm{Cu}$ concentration of $27.9 \mathrm{mg} \mathrm{dm}^{-3}$; $\mathrm{Zn}$ concentration of $23.4 \mathrm{mg} \mathrm{dm}^{-3}$; Mn concentration of $209.0 \mathrm{mg}$ $\mathrm{dm}^{-3} ;$ Fe concentration of $31.2 \mathrm{mg} \mathrm{dm}$.

The area was planted with Tifton 85 grass for eight years and is exclusively used for the production of hay and haylage and the only fertilizer source used is SW. SW was processed by anaerobic digestion, where by it was treated in a continuousflow biodigester Canadian model, with a capacity of 3,200 $\mathrm{m}^{3}$ and 45 day of hydraulic retention time. The effluent was carried to a storage pond that was covered with a black plastic blanket, and had a capacity of $2,475 \mathrm{~m}^{3}$.

The SW pig farm was characterized as a confined unit for the production of breeding pigs, which had pig barn, and approximately 3,600 animals, including lactating sows, pregnant pigs, and piglets. The unit had pig barn that were categorized as nursery, maternity, and pregnancy rooms. The piglets remainedin the farm until they reached approximately the age of 30 days.

SW from several pig barn (affluent) was carried to the biodigester via concrete side channels and the facilities were cleaned daily. Upon leaving the biodigester, the produced SW was conveyed to the effluent tank and pumped into the storage pond with a capacity of $900 \mathrm{~m}^{3}$, which was located in the hay and haylage production area.

Pumping was done once or twice a week, according to the amount of SW produced and the need for hay and haylage production. This was sprayed on the surface area of hay and haylage production using a coupled spraying equipment after 7 and 14 days of forage regrowth, at an average of $60 \mathrm{~m}^{3} \mathrm{ha}^{-1}$ per application. Due to the decanting process, prior to application, SW was homogenized with as praying equipment that was coupled to the tractor. The chemical analysis of SW by flame 
atomic absorption spectrometry (FAAS) revealed the following composition: $0.80 \mathrm{~g} \mathrm{~kg}^{-1}$ of $\mathrm{N}, 0.96 \mathrm{~g}$ $\mathrm{L}^{-1}$ of $\mathrm{K}, 4.62 \mathrm{~g} \mathrm{~L}^{-1}$ of P, $0.64 \mathrm{~g} \mathrm{~L}^{-1}$ of Ca, $0.03 \mathrm{~g} \mathrm{~L}^{-1}$ of $\mathrm{Mg}, 0.87 \mathrm{mg} \mathrm{L}^{-1}$ of Cu, $0.45 \mathrm{mg} \mathrm{L}^{-1}$ of $\mathrm{Zn} 0.24 \mathrm{mg} \mathrm{L}^{-1}$ of $\mathrm{Mn}$, and $5.61 \mathrm{mg} \mathrm{L}^{-1}$ of Fe.

The density, dry matter, $\mathrm{pH}$, and temperature of
SW in the rainy and dry seasons are described in Table 1. The bromatological composition of Tifton 85 bermudagrass at the moment of cut was 269.9 $\mathrm{g} \mathrm{kg}^{-1}$ dry matter, $64.1 \mathrm{~g} \mathrm{~kg}^{-1}$ mineral matter, 133.9 $\mathrm{g} \mathrm{kg}^{-1}$ crude protein, $705.9 \mathrm{~g} \mathrm{~kg}^{-1}$ neutral detergent fiber and $314.2 \mathrm{~g} \mathrm{~kg}^{-1}$ acid detergent fiber.

Table 1. Dry matter (DM), density, $\mathrm{pH}$, and temperature of swine wastewater and ambient temperature at the site of production and the site of application in the rainy and dry seasons.

\begin{tabular}{|c|c|c|c|c|c|}
\hline \multicolumn{6}{|c|}{ Rainy season } \\
\hline Local & $\mathrm{DM}$ & Density & $\mathrm{pH}$ & Temp. (SW) & Temp. (ambient) \\
\hline & $\%$ & $\mathrm{~g} \mathrm{ml}^{-1}$ & & & ${ }^{\circ} \mathrm{C}$ \\
\hline Affluent & 0.46 & 0.94 & 8.20 & 25.40 & 34.00 \\
\hline Effluent & 0.21 & 0.96 & 7.50 & 29.90 & 34.00 \\
\hline Pond & 0.21 & 0.93 & 7.40 & 26.70 & 31.30 \\
\hline \multicolumn{6}{|c|}{ Dry season } \\
\hline \multirow[t]{2}{*}{ Local } & $\mathrm{DM}$ & Density & $\mathrm{pH}$ & Temp. (SW) & Temp. (ambient) \\
\hline & $\%$ & $\mathrm{~g} \mathrm{ml}^{-1}$ & & & ${ }^{\circ} \mathrm{C}$ \\
\hline Affluent & 0.54 & 0.96 & 8.23 & 12.80 & 21.50 \\
\hline Effluent & 0.27 & 0.96 & 7.84 & 18.60 & 21.00 \\
\hline Pond & 0.16 & 0.95 & 8.14 & 15.00 & 18.80 \\
\hline
\end{tabular}

The experimental design for the microbiological evaluation was completely randomized with subdivided plots and five replications, and the main plots were the area of the swine wastewater production, the biodigester outlet (effluent), the storage pond, the soil, residue of the plants on the soil surface (organic matter - OM) and the aerial parts (AP) of the grasses in the area of Tifton 85 production with subplots in the rainy season (RS) and dry season (DS). Microbiological analyses were carried out the day before the Tifton 85 grass was cut during two seasons, rainy and dry, after an average of 40 days of regrowth for the production of hay and haylage.

The preparation of the samples for microbiological analysis consisted of a previous dilution through the collection of $25 \mathrm{~g}$ of sample for soil, organic matter, and plant. The samples of affluent, effluent and storage pond were conditioned in sterile bottles, refrigerated, and transported to the laboratory when the initial dilution was obtained. Microbial populations were determined by selective culture techniques: $25 \mathrm{~g}$ of samples were added to $225 \mathrm{ml}$ of sterile distilled water. From the solution obtained, $1 \mathrm{ml}$ was pipetted with dilutions ranging from $10^{1}$ to $10^{9}$ using test tubes for dilution water containing $9 \mathrm{ml}$ of sterile distilled water.

The counts of molds and yeasts, Clostridium, Bacillus and enterobacteria were performed according to Beuchat and Cousin (2001), Labbe (2001), and Vanderzant and Splittstoesser et al. (1992), respectively, during the rainy season and the dry season. The results were obtained in selected dilution, and expressed as $\log$ of $\mathrm{CFU} \mathrm{g}^{-1}$. The molds 
were isolated by inducing mycelial growth on potato dextrose agar medium through the induction of sporulation or by direct isolation of the spores (reproductive structures) of the pathogens from the collected samples (FERNANDEZ, 1993).

For the observation under a stereoscopic microscope (or a magnifying glass), semi-permanent slides of all the fungal structures, both in the symptomatic material and in the culture medium, were prepared. These structures were transferred onto a microscope slide using a needle or stylus, stained with lactophenol cotton blue, covered with a coverslip, sealed with enamel, and observed under an optical microscope for the identification of molds with the aid of specific identification keys (SAMSON et al., 1995).

Data were subjected to analysis of variance using the SISVAR program (FERREIRA, 1998), at 5\% level of significance. When significant differences between the treatments for the variables under study were detected, they were compared by the Tukey's test at the same level of significance. The average values were calculated for the identification of mold genera, and subjected to descriptive analysis.

\section{Results and Discussion}

The populations of Clostridium and enterobacteria were larger in the affluent than in the effluent, storage pond, AP, OM, and soil $(\mathrm{P}<0.05)$ (Table 2). However, for Bacillus, the same did not occur. There was a gradual decrease in the microbial counts among the production site (affluent), biodigester outlet (effluent) and storage pond, which demonstrated that the SW sprayed on the soil (storage pond) had lower counts than the material in natura (affluent), thereby demonstrating the efficiency of the SW treatment. There was no decrease in microbial counts except for that of Bacillus in the dry season.

Schmidt et al. (2003) verified a lower diversity of microorganisms in the effluent than in the affluent, and demonstrated the tendency of decrease in the diversity of microorganisms throughout the manure treatment system. This lower population of microorganisms in the effluent possibly implies the disappearance of the bacteria that were which did not survive the different environmental conditions of the ponds (CHO; KIM, 2000).

Table 2. Population of bacteria in swine wastewater at the site of production, the site of application, during the rainy season and the dry season.

\begin{tabular}{|c|c|c|c|c|c|c|}
\hline & & & Clo & & Ent & \\
\hline & & & $-\log$ & & & \\
\hline Local & $\mathrm{RS}$ & $\overline{\mathrm{DS}}$ & $\mathrm{RS}$ & DS & $\mathrm{RS}$ & DS \\
\hline Affluent & $6,78 \mathrm{bA}$ & $4,59 \mathrm{bB}$ & $12,55 \mathrm{aA}$ & $8,21 \mathrm{aB}$ & $7,35 \mathrm{aA}$ & $7,21 \mathrm{aA}$ \\
\hline Effluent & $7,98 \mathrm{aA}$ & $4,60 \mathrm{bB}$ & $10,73 \mathrm{bA}$ & $6,77 \mathrm{bB}$ & $4,89 \mathrm{cB}$ & $5,77 \mathrm{bA}$ \\
\hline Pond & $5,72 \mathrm{dA}$ & $4,73 \mathrm{bB}$ & $10,72 \mathrm{bA}$ & $6,18 \mathrm{cB}$ & $4,85 \mathrm{cA}$ & $4,62 \mathrm{cB}$ \\
\hline $\mathrm{AP}$ & $7,77 \mathrm{aA}$ & $3,67 \mathrm{cB}$ & $10,58 \mathrm{bA}$ & $5,70 \mathrm{~dB}$ & $5,72 \mathrm{bB}$ & $5,97 \mathrm{bA}$ \\
\hline $\mathrm{OM}$ & $5,84 \mathrm{cdA}$ & $5,61 \mathrm{aB}$ & $6,98 \mathrm{cA}$ & $6,81 \mathrm{bB}$ & $5,93 \mathrm{bA}$ & $5,91 \mathrm{bA}$ \\
\hline Soil & $6,15 \mathrm{cA}$ & $4,64 \mathrm{bB}$ & $6,06 \mathrm{dA}$ & $6,69 \mathrm{bB}$ & $0,00 \mathrm{~dB}$ & $2,94 \mathrm{dA}$ \\
\hline$\overline{\mathrm{CV}(\%)_{1}}$ & & & & & & \\
\hline $\mathrm{CV}(\%)_{2}$ & & & & & & \\
\hline
\end{tabular}

Values followed by the same letter, lowercase in the columns and uppercase in the line, do not differ by the Tukey's test at $5 \%$ level of significance.

$\mathrm{CV}(\%) 1$ : and $\mathrm{CV}(\%) 2$ : coefficients of variation of plot and subplot respectively

AP: aerial part, OM: organic matter, RS: rainy season, DS: dry season and CV: coefficient of variation. 
It was observed that larger populations of Bacillus and Clostridium were found in the affluent, effluent, storage pond, AP, OM and soil during the rainy season than during the dry season (Table 2), thus showing that high humidity and temperature could be the factors that influenced the growth of these microorganisms.

By comparing the values of SW in the storage pond and in the AP of Tifton 85 cultivation, it can be observed that the microbial load in SW remained on the aerial parts of the Tifton 85 grasses was able to increase according to the climatic conditions. Such an increase in the populations of Bacillus and Clostridium was observed, mainly during the rainy season (Figure 1a), when the temperature and relative humidity were more favorable to their growth. According to Blakeman (1981), most of the microorganisms present in the plants are found on the leaves at the base of the stem, where they are more protected from radiation, and humidity is higher.

In relation to the mold and yeast counts, the
SW area was observed to exhibit various genera of molds, such as Penicillium, Rhizopus, Fusarium, Helminthosporium, and Phoma, in addition to a large population of yeasts, which favor the rapid decomposition of silage and haylage in particular (Figure 2).

In the areas of SW (affluent, effluent, and storage pond), larger populations were obtained in the affluent during the rainy and dry seasons, with a mean of 2.97 $\mathrm{Log} \mathrm{CFU} \mathrm{g}^{-1}$ and 3.66 $\mathrm{Log}_{\mathrm{CFU} \mathrm{g}}{ }^{-1}$, respectively. There was a reduction in the counts and populations of the molds and yeasts because of the process of SW production, whereby they were reduced to less than $2 \mathrm{Log} C F U \mathrm{~g}^{-1}$ in the effluent and 0.5 $\mathrm{Log}_{\mathrm{CFU} \mathrm{g}}{ }^{-1}$ in the storage pond. Despite the diversity of the molds found in SW, this indicated that the SW that was sprayed on the Tifton 85 grasses was not an initiator of the high microbial counts in hay, haylage or silage that would be produced subsequently. Rammer et al. (1997), and Anderson and Christie (1998) classified the risk of using liquid fertilizers for forage crops as low.

Figure 2. Molds and yeasts in the areas of swine wastewater production during the rainy season (A) and the dry season (B). Values followed by the same letter do not differ by the Tukey's test at 5\% level of significance.

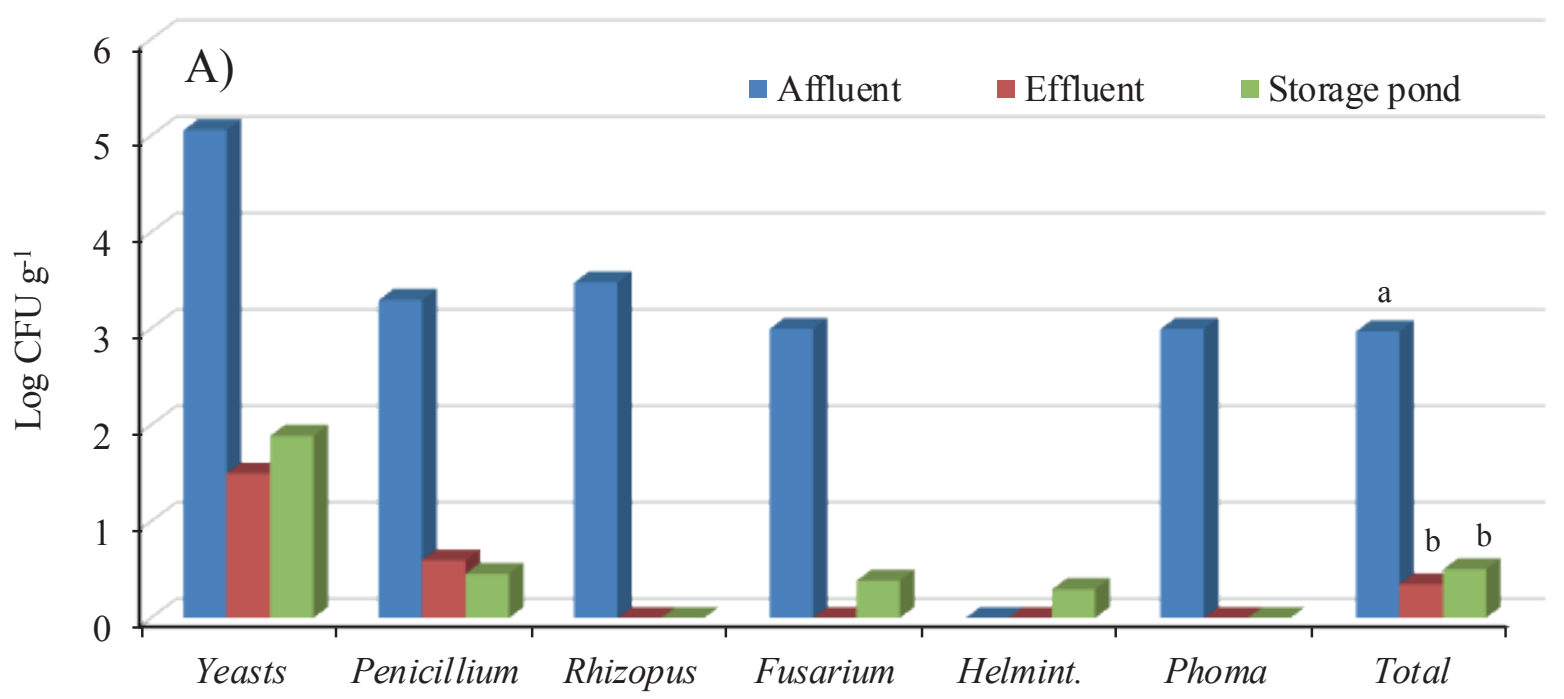

Semina: Ciências Agrárias, Londrina, v. 39, n. 2, p. 797-808, mar./abr. 2018 


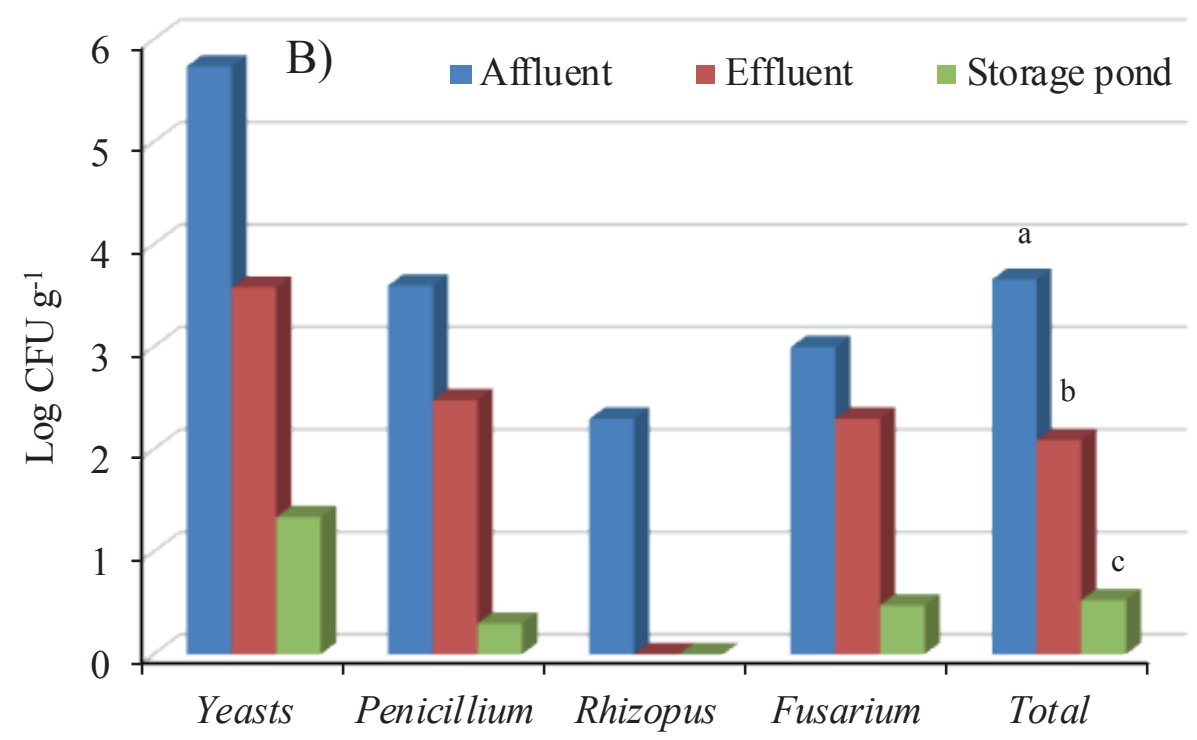

*Helmint.: Helminthosporium.

Nine genera of molds were isolated during the rainy season: Penicillium (16,89\%), Rhizopus (4,83\%), Fusarium (15,53\%), Cladosporium (13,78\%), Helminthosporium (13.04\%), Bipolaris (4.83\%), Phoma (7.78\%), Aspergillus (3.89\%), and Trichoderma (4.48\%), in addition to yeast $(14,98 \%)$ (Figure 3). Variations in the mold genera were observed between the dry and rainy seasons. However, Penicillium, Rhizopus, and Fusarium persisted during the dry season and the rainy season. Molds such as Penicillium, Fusarium, and Aspergillus favor the decomposition of hay bales, and pose a risk to animal health, mainly since they persist after days of storage. According to Belém
(1994), these are the dominant mold genera that have a high ability to produce mycotoxins.

In the area of Tifton 85 production, including the AP of the grasses, OM and soil, no statistical difference $(\mathrm{P}>0.05)$ in the total mold and yeast counts during the rainy season was observed. However, during the dry season, there were higher counts of molds and yeasts in the OM than in the soil and the AP of Tifton 85 production (Figure 3). According to Mufatto et al. (2016), greater fungal population was observed in soil and dead plant material, predominantly Penicillium in all parts of the plant studied. 
Figure 3. Molds and yeasts in the area of Tifton 85 grass production, aerial part, organic matter, and soil during the rainy season (A) and the dry season (B). Values followed by the same letter do not differ by the Tukey's test at 5\% level of significance.
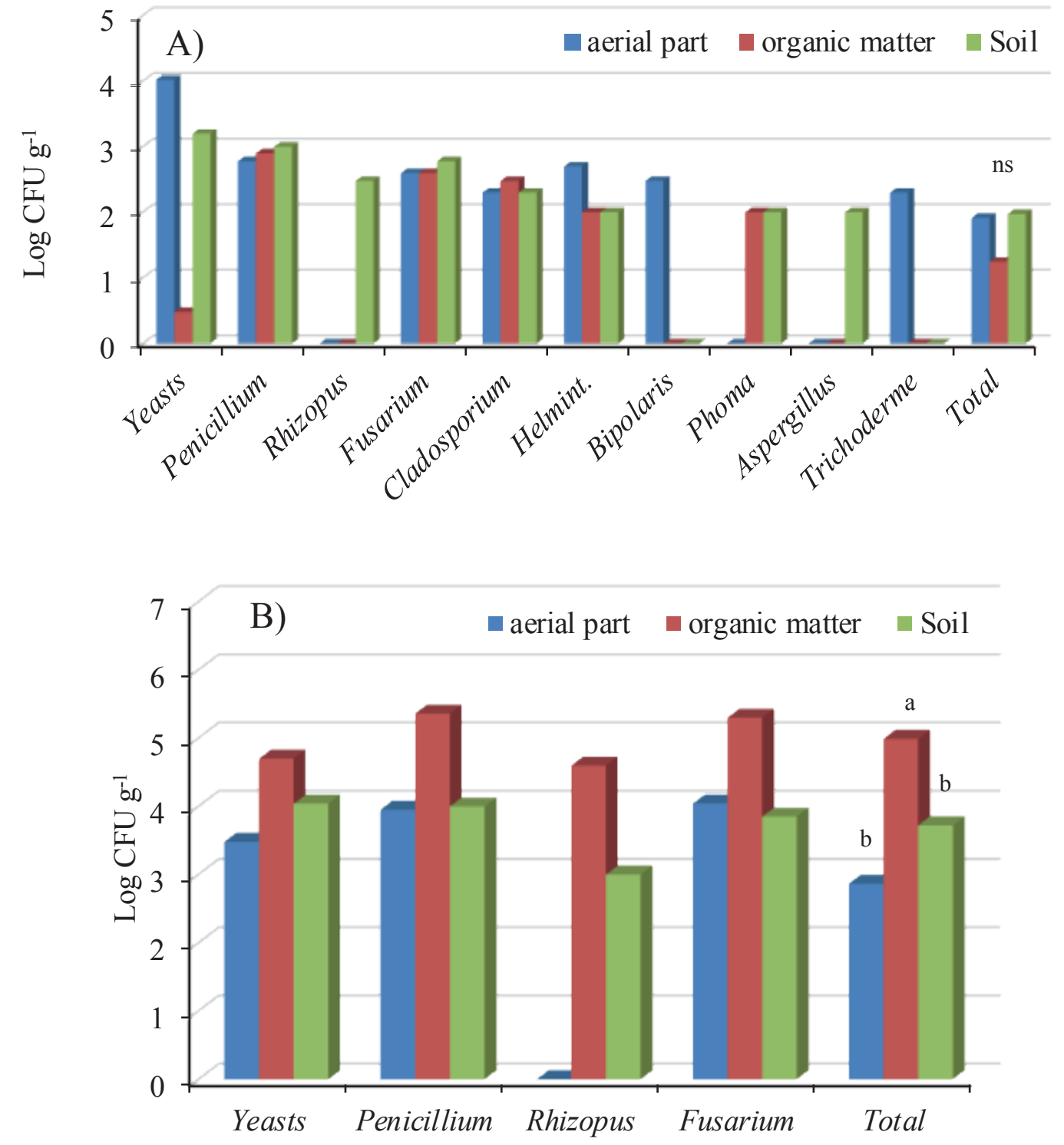

*Helmint.: Helminthosporium. 
The most frequent mold genera in the soil were Penicillium, Fusarium, and Rhizopus. There is a great diversity of molds found in the soil, however, the most frequently isolated genera are Mucor, Penicillium, Trichothecium, and Aspergillus, followed by Rhizopus, Zygorhynchus, Fusarium, Cephalosporium, and Verticillium (ROITMAN et al., 1991).

Ames et al. (2014) obtained values lower than 30 $\mathrm{CFU} \mathrm{g}^{-1}$, and identified the mold genera Penicillium, Cladosporium, Phoma, Fusarium and Diplococcium, when they evaluated Tifton 85 before harvesting. Corroborating with the results obtained in this study on the aerial part of the Tifton 85 grasses. Similarly, Schocken-Iturrino et al. (2005) evaluated the genera Aspergillus, Alternaria, Pithomyces, Curvularia, Fusarium, Cladosporium, Phoma, Epicoccum, Nigrospora, and Helminthosporium.

\section{Conclusions}

The microbial count in the swine wastewater was reduced during the treatment process, with higher counts in the affluent, and lower counts in the effluent and storage pond. The biodigester treatment was efficient in reducing the SW microbial populations.

The populations of Bacillus and Clostridium were influenced by the season of the year, with larger populations in the rainy season (summer) than in the dry season (winter).

The mold genera that were identified in the area of SW production were Penicillium, Rhizopus, Fusarium, Helminthosporium, and Phoma. The genera Penicillium, Rhizopus, Fusarium, Cladosporium, Helminthosporium, Bipolaris, Phoma, Aspergillus, and Trichoderma were identified in the area of Tifton 85 cultivation.

\section{Acknowledgment}

We are grateful to the National Council for Scientific and Technological Development - CNPq, for having made this research possible and for the financial support.

We are also grateful to the Coordination for the Improvement of Higher Education Personnel CAPES for granting the scholarship.

\section{References}

AMES, J. P.; NERES, M. A.; CASTAGNARA, D. D.; MUFATTO, L. M.; DUCATI, C.; JOBIM, C. C.; TRES, T. T. Dry matter production, chemical composition, dry matter digestibility and occurrence of fungi in Bermuda grass hay (Cynodon dactylon) under different fertilization systems or associated with pea plantings in winter. Ciencia e Investigación Agraria, Santiago, v. 41, n. 2, p. 5-6, 2014.

ANDERSON, R.; CHRISTIE, P. Effect of longterm application of animal slurries to grass on silage feeding quality for sheep. Journal of the Science of Food and Agriculture, Medford, v. 78, n. 1, p. 53-58, 1998.

BELÉM, P. A. D. Introdução ao estudo das micotoxinas de interesse em medicina veterinária. Viçosa, MG: Universidade Federal de Viçosa, 1994. 18 p.

BEUCHAT, L. R.; COUSIN, M. A. Yeasts and molds. In: DOWNES, F. P.; ITO, K. (Ed.). Compendium of methods for the microbiological examination of foods. Washington: Apha, 2001. p. 209-215.

BLAKEMAN, J. P. Microbial ecology of the phylloplane. London: Academic Press, 1981. 502 p.

CHO, J. C.; KIM, S. J. Increase in bacterial community diversity in subsurface aquifers receiving livestock wastewater input. Applied and Environmental Microbiology, Washington, v. 66, n. 3, p. 956-965, 2000.

EMPRESA BRASILEIRA DE PESQUISA AGROPECUÁRIA - EMBRAPA. Sistema brasileiro de classificação de solos. 3. ed. Rio de Janeiro: Embrapa Solos, 2013. 353 p.

FERNANDEZ, M. R. Manual para laboratório de fitopatologia. Passo Fundo: EMBRAPA CNPT, 1993. $128 \mathrm{p}$.

FERREIRA, D. F. Sisvar: sistema de análise de variância para dados balanceados. Lavras: UFLA, 1998. CD-ROM.

FREIRE, F. C. O.; VIEIRA, I. G. P.; GUEDES, M. I. F.; MENDES, F. N. P. Micotoxinas: importância na alimentação e na saúde humana e animal. Fortaleza: EMBRAPA Agroindústria Tropical, 2007. $48 \mathrm{p}$. (Documento, 110). 
HAMAWAND, I. Anaerobic digestion process and bio-energy in meat industry: a review and a potential. Renewable and Sustainable Energy Reviews, v. 44, p. 37$51,2015$.

KORZENIEWSKA,E.;ZIELIŃSK,M.;FILIPKOWSKA, Z.;DĘBOWSKI, M.; KWIATKOWSKI, R. Methanogenic archaeon as biogas producer in psychrophilic conditions. Journal of Cleaner Production, v. 36, p. 190-194, 2014.

LABBE, R. G. Clostridium perfringens. In: DOWNES, F. P.; ITO, K. (Ed.). Compendium of methods for the microbiological examination of foods. Washington: Apha, 2001. p. 325-330.

MATA-ALVAREZ, J.; DOSTA, J.; ROMERO-GÜIZA, M. S.; FONOLL, X.; ASTALS, S. A critical review on anaerobic co-digestion achievements between 2010 and 2013. Renewable and Sustainable Energy Reviews, v. 36, p. 412-427, 2014.

MENEZES, J. F. S.; ALVARENGA, R. C.; ANDRADE, C. L. T.; KONZEN, E. A.; PIMENTA, F. F. Aproveitamento de resíduos orgânicos para a produção de grãos em sistema de plantio direto e avaliação do impacto ambiental. Revista Plantio Direto, Passo Fundo, v. 9, n. 1, p. 30-35, 2003.

MUFATTO, L. M.; NERES, M. A.; NATH, C. D.; STANGARLIN, J. R.; SCHEIDT, K. C.; CASAROTTO, L.; SARTO, J. R. W.; SUNAHARA, S. M. M. Caracterização e quantificação da população de fungos em área de produção de feno de capim Tifton 85, adubado com biofertilizante suíno. Ciência Rural, Santa Maria, v. 46, n. 3, p. 486-491, 2016.

MULLER, C. E.; JOHANSSON, M.; SALOMONSSON, A. C.; ALBIHN, A. Effect of anaerobic digestion residue vs. Livestock manure and inorganic fertilizer on the hygienic quality of silage and haylage in bales. Grass and Forage Science, v. 69, n. 1, p. 74-89, 2013.

PESSUTO, J.; SCOPEL, B. S.; PERONDI, D.; GODINHO, M.; DETTMER, A. Enhancement of biogas and methane productionby anaerobic digestion of swine manure withaddition of microorganisms isolated from sewagesludge. Process Safety and Environmental Protection, v. 104, p. 233-239, 2016.
POSCHL, M.; WARD, S.; OWENDE, P. Evaluation of energy efficiency of various biogas production and utilization pathways. Applied Energy, v. 87, n. 11, p. 3305-3321, 2010.

RAMMER, C.; LINGVALL, P.; SALOMON, E. Ensiling of manured crops - does repeated spreading of slurry increase the hygienic risks? Journal of the Science of Food and Agriculture, v. 73, n. 3, p. 329-336, 1997.

ROITMAN, I.; TRAVASSOS, L. R.; AZEVEDO, J. L. Tratado de microbiologia. São Paulo: Manole, 1991. v. 2, $126 \mathrm{p}$.

SAMSON, R. A.; HOEKSTRA, E. S.; FRISVAD, J. C. Introduction to food-borne fungi. Baarn: CBS, 1995. 322 p.

SCHMIDT, I.; SLIEKERS, O.; SCHMID, M.; BOCK, E.; FUERST, J.; KUENEN, J.; JETTEN, M.; STROUS, M. New concepts of microbial treatment process for the nitrogen removal in wastewater. FEMS Microbiology Reviews, v. 27, n. 4, p. 481-492, 2003.

SCHOCKEN-ITURRINO, R. P.; REIS, R. A.; COAN, R. M.; BERNARDES, T. F.; PANIZZI, R. C.; POIATTI, M. L.; PEDREIRA, M. S. Alterações químicas e microbiológicas nas silagens de capim-tifton 85 após a abertura dos silos. Revista Brasileira de Zootecnia, Viçosa, MG, v. 34, n. 2, p. 464-471, 2005.

VANDERZANT, C; SPLITTSTOESSER, D. F. Compendium of methods for the microbiological examination of foods. $3^{\text {th }}$ ed. Washington: American Public Health Association, 1992. 1219 p.

YAN, Z.; SONG, Z.; LI, D.; YUAN, Y.; LIU, X.; ZHENG, $\mathrm{T}$. The effects of initial substrate concentration, $\mathrm{C} / \mathrm{N}$ ratio, and temperature on solid-state anaerobic digestion from composting rice straw. Bioresource Technology, Miramar, v. 177, p. 266-273, 2015.

ZHOU, J.; ZHANG, R.; LIU, F.; YONG, X.; WU, X.; ZHENG, T.; JIANG, M.; JIA, H. Biogas production and microbial community shift through neutral $\mathrm{pH}$ control during the anaerobic digestion of pig manure. Bioresource Technologyv, Miramar, v. 217, p. 44-49, 2016. 
